\title{
Genzyme deal set to alter biotech landscape
}

\section{Maintaining innovative culture will be a key challenge for new owners of industry stalwart.}

BY HEIDI LEDFORD

$\mathrm{W}$ hen the biotech company Genzyme first opened for business in 1981 in Cambridge, Massachusetts, it shared a building with a discount women's clothing store. "In the elevators you would see women looking for bargains, mixed in with these corporate types in suits, and technicians carrying mice in cages," recalls Harvey Lodish of Cambridge's Whitehead Institute, who was one of the company's founding scientists.

Thirty years on, with 10,000 employees, US $\$ 4$ billion in annual sales and a towering glass edifice for its head office, Genzyme is about to start a new life as a branch of the pharmaceutical giant sanofi-aventis. The \$20-billion deal, announced on 16 February, is the industry's biggest in two years. But some observers fear that the company's shift to the status of a branch plant will dilute the homegrown innovative culture for which Genzyme is known, and drain some of the dynamism from the biotech hub it has helped to create in the area around Boston.

Genzyme proved that designing therapies for rare diseases can be profitable. Early on, Genzyme scientists developed Ceredase, an enzyme obtained from human placentas to treat Gaucher's disease, an enzyme-deficiency disorder, and later followed it up with Cerezyme, a similar enzyme grown in mammalian cell cultures. It is Genzyme's expertise with therapeutic enzymes and experience with rare diseases that attracted sanofi.

The pattern has become a familiar one in recent years: a pharmaceutical giant acquires a smaller biotech company as a way of stocking up on new drug candidates (see 'Big buys'). The risk is that the culture clash between a larger, mature firm and its smaller, leaner acquisition can chase away the talent that the acquiring company was hoping to tap, says Josh Lerner, who studies entrepreneurship at Harvard Business School in Boston.

"Everyone's nervous" about the Genzyme deal, says Lodish, who no longer has a stake in the company. "It's a big unknown."

Genzyme is hardly a young start-up, but it is still more nimble than big pharma, says Alison Taunton-Rigby, chief executive of RiboNovix in Natick, Massachusetts, and a former senior vice-president at Genzyme. "No matter what

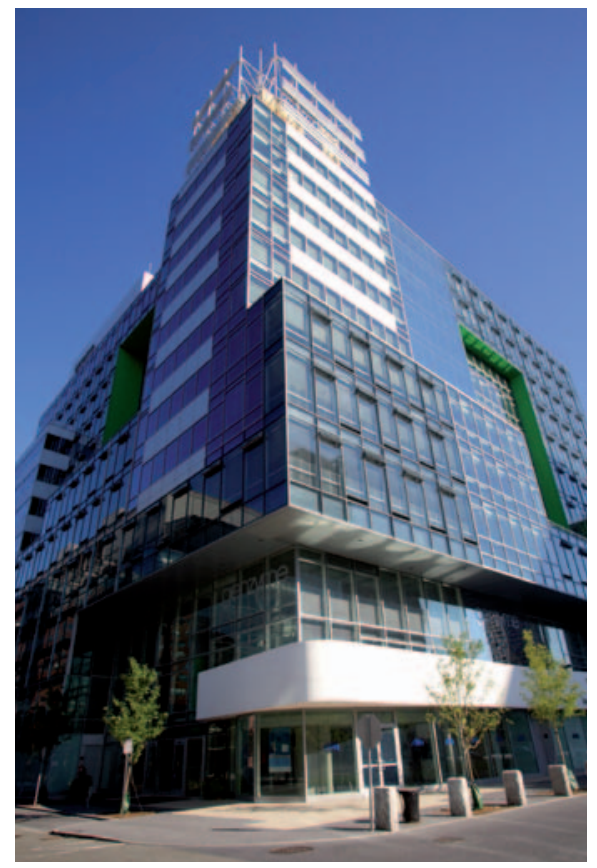

Genzyme: a cornerstone of Boston-area biotech.

big pharma does, it is different from biotech, and different people are drawn to these two different cultures," she says.

When Swiss pharmaceutical maker Roche fully acquired Genentech in 2009, for example, a mass exodus of talent ensued. Genentech, headquartered in South San Francisco, California, was renowned for its highly innovative culture, which attracted a steady flow of top-calibre scientists from academia. Despite Roche's assurances that its new acquisition would remain largely independent, many of Genentech's top executives left soon after the purchase was announced. "Since then, talented

\section{BIG BUYS}

The top five biotechnology acquisitions by pharma.

\begin{tabular}{l|l|l|l|} 
Biotech & Pharma & $\begin{array}{l}\text { Price (US\$ } \\
\text { billion) }\end{array}$ & Year \\
Genentech & Roche & 46.8 & 2009 \\
Genzyme & sanofi-aventis & 20.1 & 2011 \\
\hline Medlmmune & AstraZeneca & 15.6 & 2007 \\
Serono & Merck KGaA & 13.3 & 2007 \\
Millennium & Takeda & 8.8 & 2008
\end{tabular}

people from Genentech have peppered the whole West Coast with biotech start-ups," says Neil Solomon of the Neil Michael Group in Great Neck, New York, an agency that recruits senior executives for life-sciences companies. Industry watchers say it is still too soon to gauge the impact on innovation at Genentech.

\section{TROUBLE BREWING}

It is a little early to see CVs coming from the top at Genzyme, Solomon says, but he has had conversations with executives there who are preparing their exits. This could portend trouble for sanofi, which is relying on Genzyme's expertise to strengthen its presence in proteinbased therapies and the rare-diseases market.

Acquisitions by pharma do not always sound the death knell for innovation at biotechnology firms. Some say that Millennium Pharmaceuticals, another Cambridge biotechnology firm, may benefit from its acquisition by Japanese drug maker Takeda in 2008. Millennium had assembled a talented team of scientists, but its approach - to use genomics to fuel drug discovery - had foundered. In this case, the acquisition by Takeda could provide a turnaround by changing the focus or management of the company, says Gary Pisano of Harvard Business School, whose research includes the biotechnology industry.

What is clear is that the Genzyme acquisition heralds a change in the Cambridge biotech scene, says Taunton-Rigby. Genzyme and Biogen Idec, another stalwart biotech located only a few blocks away, have been the pillars of the local biotechnology community. Pressure from investors drove Biogen to seek a pharmaceutical suitor, and although none has yet come forward, the company has been cutting costs and jettisoning programmes. Just as Genzyme has become the rare-diseases division of sanofi, Biogen seems to be preparing itself to become the neurology division of a major pharmaceutical firm. These changes, says Taunton-Rigby, would sever Boston's connection to other aspects of drug development, such as marketing and production.

"The cornerstone of the business here has been these two fully independent companies," says Taunton-Rigby. "That's what made the culture here unique - when you only have research without the other capabilities, it's a very different scene." - 